DOI: 10.19112/2413-6174-2021-S1-24

\title{
ТОКСИЧЕСКИЕ ЭЛЕМЕНТЫ \\ В ТКАНЯХ МОЛОДИ СТЕРЛЯДИ (ACIPEN SERRUTHENUS) ПРИ ВКЛЮЧЕНИИ В РАЦИОН НАНОЧАСТИЦ СПЛАВА Cu-Zn И КУЛЬТУРЫ ВACILLUS SUBTILIS
}

\author{
Е.П. Мирошникова ${ }^{I}$, А.Е. Аринжанов ${ }^{1 *}$ Ю.В. Килякова ${ }^{1}$ М.С. Мирошникова ${ }^{2}$ \\ ${ }^{1}$ Оренбургский государственный университет, 460013 г.Оренбург, пр. Победы 13 \\ *e-mail: arin.azamat@mail.ru \\ ${ }^{2}$ Федеральный научный центр биологических систем и агротехнологий Российской академии наук \\ 460000, г. Оренбург, ул. 9 Января 29
}

РЕЗЮМЕ. Представлены результаты исследования влияния наночастиц сплава Cu-Znразмером $55 \pm 15$ нм и культуры Bacillus subtilis (пробиотический препарат Ветом 1.1) при включении в рацион молоди стерляди (Acipen serruthenus) на обмен токсических элементов. По принципу аналогов было сформировано четыре группы: контрольная и три опытные. В рацион I опытной группы добавляли пробиотический препарат (25 мг/кг корма), рыбам II группы добавляли наночастицы сплава $\mathrm{Cu}-\mathrm{Zn}$ (2,84 мг/кг корма), рыбам III группы в рацион добавляли пробиотический препарат (25 мг/кг корма) и наночастицы сплава $\mathrm{Cu}-\mathrm{Zn}$ (2,84 мг/кг корма). Включение в рацион рыб наночастиц и культуры Bacillus subtilis как вместе, так и отдельно сопровождается снижением концентрации группы токсических элементов в теле рыб: алюминия, кремния, мышьяка, ртути и свинца. Выявлен синергизм действия пробиотика и наночастиц меди и цинка - совместное включение в рацион приводитк снижению концентрации токсических элементов в организме рыб и к стабилизации обменных процессов, дифференциации клеток и поддержанию антиоксидантного статуса организма рыб.

КЛЮЧЕВЫЕ СЛОВА: наночастицы, микроэлементы, стерлядь, питание, медь, цинк.

\section{TOXIC ELEMENTS IN JUVENILE STERLET TISSUE (ACIPEN SERRUTHENUS) AT THE INCLUSION OF Cu-Zn ALLOY AND BACILLUS SUBTILIS CULTURE IN DIET}

\author{
E.P. Miroshnikova ${ }^{1}$, A.E. Arinzhanov ${ }^{1 *}$, Y.V. Kilyakova ${ }^{1}$, M.S. Miroshnikova ${ }^{2}$ \\ ${ }^{1}$ Orenburg State University, 460013 Orenburg, Pr. Pobedy 13 \\ *e-mail: arin.azamat@mail.ru \\ ${ }^{2}$ Federal Research Centre of Biological Systems and Agro-technologies of the Russian Academy of Sciences, \\ 460000 Orenburg, ul. 9 Yanvarya 29
}

ABSTRACT. The article presents the research results of nanoparticles influence of $\mathrm{Cu}-\mathrm{Zn}$ alloy with size of $55 \pm 15 \mathrm{~nm}$ and Bacillus subtilis culture (Vet 1.1 probiotic product) at the inclusion in diet of juvenile sterlet (Acipenser ruthenus) on exchange of toxic elements. According to the analogues principle, four groups were formed: control and three test groups. The probiotic product $\left(25 \mathrm{mg} / \mathrm{kg}\right.$ feed) was added to the diet of the $1^{\text {st }}$ test group, nanoparticles of $\mathrm{Cu}-\mathrm{Zn}$ alloy $\left(2.84 \mathrm{mg} / \mathrm{kg}\right.$ feed) were added to fish of the $2^{\text {nd }}$ group, and the probiotic product $(25 \mathrm{mg} / \mathrm{kg}$ feed) and Cu- $\mathrm{Zn}$ alloy nanoparticles $\left(2.84 \mathrm{mg} / \mathrm{kg}\right.$ feed) were added to the diet of the $3^{\text {rd }}$ group. The inclusion of nanoparticles and Bacillus subtilis culture in fish diet both together and separately is accompanied by a decrease in the concentration of the toxic elements group in fish body: aluminum, silicon, arsenic, mercury and lead. Synergism of probiotic action and copper and zinc nanoparticles at simultaneous inclusion in diet is revealed. It leads to the reduction of the toxic elements concentration in fish body and to the stabilization of metabolic processes, the cells differentiation and the antioxidant status maintenance of fish body.

KEYWORD: nanoparticles, trace elements, sterlet, nutrition, copper, zinc.

\section{ВВЕДЕНИЕ}

В качестве минеральных добавок для оптимизации состава рационов перспективно использование микроэлементов в наноформе, что объясняется их способностью легко проникать во все органы и ткани организма и стимулировать обменные процессы. 
Цель работы - изучение особенностей обмена токсических элементов в тканях молоди стерляди при включении в рацион рыб наночастиц (НЧ) сплава $\mathrm{Cu}-\mathrm{Zn}$ и культуры Bacillus subtilis.

\section{МАТЕРИАЛЫ И МЕТОДЫ}

Исследования выполнены на молоди стерляди (Acipenser ruthenus), возраст - 7 месяцев; живая масса 70-90 г. По принципу аналогов были сформированы четыре группы $(n=15)$ : контрольная - основной рацион (OP), I опытная - ОР с добавлением пробиотического препарата (25 мг/кг корма), II - OP с НЧ $\mathrm{Cu}-\mathrm{Zn}$ (2,84 мг/кг корма), III-OP с пробиотиком (25 мг/кг корма) и $\mathrm{HЧ} \mathrm{Cu-Zn} \mathrm{(2,84} \mathrm{мг/кг} \mathrm{корма).} \mathrm{В}$ исследованиях использовали полученные методом плазмохимического синтеза $\mathrm{HЧ} \mathrm{Cu}-\mathrm{Zn}(\mathrm{Cu}(40 \%)-\mathrm{Zn}$ (60\%)) размером $55 \pm 15$ нм, Z-потенциал $31 \pm 0,1 \mathrm{mB}, \mathrm{S}_{\mathrm{y}}=9 \pm 0,8 \mathrm{~m}^{2} / \Gamma$. В качестве пробиотического препарата использовали Ветом 1.1 (Bacillus subtilis ВКПМ В-10641 (DSM 24613), $1 \times 10^{9}$ KOE/г).

\section{РЕЗУЛЬТАТЫ И ОБСУЖДЕНИЕ}

Общее содержание токсических элементов в организме рыб контрольной группы составило 0,437 мкмоль/кг, что оказалось выше опытных групп: I - на 23,8\%, II на 24,5\%, III на 33,2\%. Включение пробиотикав рацион привело к достоверному снижению $\mathrm{Al}(3,91$ мкг/г) в организме на $50 \%(p \leq 0,05), \mathrm{Hg}$ $(0,01$ мкг $/ \Gamma)$ на $57,6 \%(p \leq 0,05)$, As $(0,28$ мкг/г) на $65,8 \%(p \leq 0,05)$ относительно контроля. Введение в рацион НЧ сплава $\mathrm{Cu}-\mathrm{Zn}$ предполагало антагонистическое взаимодействие между элементами из-за конкуренции за общие транспортеры металлов в кишечнике (Ranganathan et al., 2011) и повышение уровня токсических элементов, но введение НЧ сопровождалось снижением As $(0,28$ мкг/г) на 41,5\% $(p \leq 0,05), \mathrm{Al}(1,94$ мкг/г) на $79 \%(p \leq 0,001), \mathrm{Hg}(0,01$ мкг/г) на 50,0\% $(p \leq 0,05)$ по отношению к контролю. При совместном включение в рацион Bacillus subtilis и НЧ также зафиксировано достоверное снижение $\mathrm{Al}(1,56$ мкг/г) в организме на $83,1 \%(p \leq 0,05), \mathrm{Hg}(0,01$ мкг/г) на 57,6\% $(p \leq 0,05)$, As $(0,46$ мкг/г) на 43,9\% $(p \leq 0,05)$ относительно контроля. Поступление в организм $\mathrm{Cu}$ и $\mathrm{Zn}$ в наноформе предполагало снижение уровня $\mathrm{Cd}$ во II и III опытных группах, так как $\mathrm{Cu}$ и $\mathrm{Zn}$ способствуют образованию металлотионинов, участвующих в выведении $\mathrm{Cd}$ из организма, но такую картину наблюдали только при сочетанном использовании НЧ и пробиотика.

\section{ВЫВОДЫ}

Сочетанное включение в рацион молоди стерляди НЧ сплава Cu-Zn и культуры Bacillus subtilis способствует снижению концентрации токсических элементов в организме, что объясняется синергизмом действия данных препаратов и приводит к стабилизации обменных процессов, дифференциации клеток и поддержании антиоксидантного статуса организма.

\section{Список литературы / References}

1. Ranganathan P.N., Lu Y., Jiang L., Kim C., Collins J.F. Serumceruloplasminproteinexpressionandactivityincreases in Iron-deficient rats and is further enhanced by higher dietary copper intake. Blood. 2011; 118(11): 3146-3153. 